OPEN ACCESS

Approved by:

Frontiers Editorial Office, Frontiers

Media SA, Switzerland

*Correspondence:

Frontiers Production Office

production.office@frontiersin.org

Specialty section:

This article was submitted to

Nuclear Physics,

a section of the journal

Frontiers in Physics

Received: 21 January 2021 Accepted: 21 January 2021

Published: 12 March 2021

Citation:

Frontiers Production Office (2021)

Erratum: Editorial: The Long-Lasting Quest for Nuclear Interactions: The Past, the Present and the Future. Front. Phys. 9:656824. doi: 10.3389/fphy.2021.656824

\section{Erratum: Editorial: The Long-Lasting Quest for Nuclear Interactions: The Past, the Present and the Future}

\author{
Frontiers Production Office* \\ Frontiers Media SA, Lausanne, Switzerland
}

Keywords: nuclear interactions, two- and three-nucleon interactions, chiral effective field theory, lattice QCD, light nuclei, Ab-initio methods

\section{An erratum on}

Editorial: The Long-Lasting Quest for Nuclear Interactions: The Past, the Present and the Future by Marcucci, L. E. (2020). Front. Phys. 8:609907. doi: 10.3389/fphy.2020.609907

Due to a production error, most references and mentions of articles were incorrectly linked. The publisher apologizes for this mistake. The original article has been updated.

Copyright $\odot 2021$ Frontiers Production Office. This is an open-access article distributed under the terms of the Creative Commons Attribution License (CC BY). The use, distribution or reproduction in other forums is permitted, provided the original author(s) and the copyright owner(s) are credited and that the original publication in this journal is cited, in accordance with accepted academic practice. No use, distribution or reproduction is permitted which does not comply with these terms. 